\title{
Analisis Pengaruh Faktor Ekonomi dan Non-Ekonomi Terhadap \\ Peningkatan Permintaan Perumahan di Kota Watampone
}

\author{
Haslinda \\ Institut Agama Islam Negeri (IAIN) Bone
}

Haslinda@gmail.com

\begin{abstract}
Abstrak
Artikel ini bertujuan untuk mengetahui dan menganalisis pengaruh faktor ekonomi dan non-ekonomi terhadap peningkatan permintaan rumah di kota Watampone. Penelitian kuantitatif ini menggunakan teknik analisis regresi linear berganda dengan responden terdiri dari penghuni perumahan yang terletak di kecamatan Tanete Riattang, Tanete Riattang Barat dan Tanete Riattang Timur di kota Watampone. Hasil penelitian ini menunjukkan faktor ekonomi tidak signifikan berpengaruh terhadap permintaan perumahan di kota Watampone. Sedangkan faktor non-ekonomi berpengaruh terhadap peningkatan permintaan perumahan di kota Watampone adalah variabel jumlah anggota keluarga, lokasi, lingkungan. Hal ini dapat dilihat dengan nilai probabilitas (signifikansi) sebesar 0,000. Kemudian diikuti oleh variabel jumlah anggota keluarga dengan nilai probabilitas sebesar 0,027.
\end{abstract}

Kata Kunci: Ekonomi, Non-Ekonomi, dan Permintaan Perumahan

\section{Pendahuluan}

Pemenuhan perumahan merupakan indikator dari kemampuan suatu negara dalam memenuhi risalah satu kebutuhan pokok penduduknya. Kondisiperumahan penduduk yang tidak memadai atau tidak dapat memenuhi kebutuhan hidup biasanya pertanda dari kekacauan ekonomi atau politik yang dihadapi masyarakat tersebut. Demikian pula perumahan yang tidak mencukupidan tidak memberikan jaminan keamanan,akan mengarah pada ketidakstabilan ekonomi dan politik yang akan menghambat pembangunan ekonomi. ${ }^{1}$

1 Panudju, Pengadaan Perumahan Perkotaan dengan Peran Serta Masyarakat Berpenghasilan Rendah, (Bandung: Alumni, 1999), hlm. 16 
Saat ini kepemilikan rumah tidak hanya ditujukan untuk pemenuhan kebutuhan pokok terhadap papan saja, namun telah menjadi suatu alternatif investasi yang cukup menarik,dengan pengembalian berupa penghasilan sewa ataupun peluang keuntungan berupa capital gain yang merupakan selisih antara harga beli dengan harga jual ketika rumah tersebut dijual.

Kepemilikan atas rumah merupakan salah satu indikator identitas status sosial di masyarakat. Jika seseorang memiliki rumah yang mewah menandakan si pemiliknya merupakan orang yang berkemampuan tinggi. Sedangkan sesorang memiliki rumah yang kecil menandakan si pemilik berasal dari kelas ekonomi yang rendah. Dewasa ini telah berkembang berbagai jenis rumah dari yang modern, seperti kondominium dan apartemen sampai jenis yang sederhana, seperti rumah susun sederhana dan rumah biasa.

Dalam Undang-Undang Republik Indonesia No.1 tahun 2011 Tentang Perumahan dan Kawasan Pemukiman dikatakan bahwa rumah adalah bangunan gedung yang berfungsi sebagai tempat tinggal yang layak huni, sarana pembinaan keluarga, cerminan harkat dan martabat penghuninya, serta aset bagi pemiliknya. ${ }^{2}$ Saat ini kepemilikan rumah tidak hanya ditujukan untuk pemenuhan kebutuhan pokok terhadap papan saja, namun telah menjadi suatu alternatif investasi yang cukup menarik, dengan pengembalian berupa penghasilan sewa ataupun peluang keuntungan berupa capital gain yang merupakan selisih antara harga beli dengan harga jual ketika rumah tersebut dijual.

Banyak faktor yang mempengaruhi seseorang dalam memilih tipe rumah yang akan digunakan sebagai tempat tinggal. Salah satu faktor dalam memilih tipe rumah adalah pendapatan yang diperoleh setiap bulannya sehingga kemampuan daya beli yang dimiliki sebanding dengan harga rumah yang ditawarkan. Menurut Awang Firdaus menjelaskan bahwa permintaan rumah dapat dipengaruhi oleh faktor-faktor yaitu harga, pendapatan,

\footnotetext{
2 Undang-Undang Republik Indonesia No. 1 Tahun 2011 Tentang Perumahan dan Kawasan Pemukiman. Pasal 1, hlm. 4
} 
pengeluaran, lokasi, kemudahan pendanaan, fasilitas/sarana umum dan selera konsumen serta peraturan perundang-undangan. ${ }^{3}$

Kota Watampone merupakan salah satu kota terbesar di SulawesiSelatan. Berdasarkan data Badan Pusat Statistik Kabupaten Bone bahwa jumlah penduduk pada tahun 2015 sebanyak 738.515 jiwa, terdiri atas 352.081 laki-laki dan 386.434 perempuan. Peningkatan jumlah penduduk tiap tahunnya mendorong pertumbuhan pembangunan perumahan di Kabupaten Bone semakin meningkat. Hal ini dapat dilihat pada tabel dibawah ini.

Tabel. Rekapitulasi Data Izin Prinsip Untuk Perumahan di Kabupatenm Bone Tahun 2011 - 2015

\begin{tabular}{|c|c|}
\hline TAHUN & JUMLAH \\
\hline 2012 & 20 \\
\hline 2013 & 19 \\
\hline 2014 & 32 \\
\hline 2015 & 22 \\
\hline 2016 & 28 \\
\hline Total & 144 \\
\hline
\end{tabular}

Sumber: Bone Dalam Angka, Promosi, dan Penanaman Modal Kabupaten Bone

Peningkatan pembangunan perumahan sejalan dengan kemajuan pertumbuhan ekonomi yang relatif tinggi di Kabupaten Bone, dimana pada tahun 2015 mencapai 8,29\% dan pada tahun 2016 mencapai 9,06\%.4 Disamping itu, dihadapkan pada kebutuhan akan rumah yang semakin besar sebagai dampak pertumbuhan ekonomi maupun jumlah penduduk yang

\footnotetext{
${ }^{3}$ Awang Firdaus, Permintaan dan Penawaran Perumahan, Jakarta: Valuestate Vol.
} $007 / 1997$.

${ }^{4}$ Laporan pertumbuhan ekonomi PDRB Kabupaten Bone tahun 2011-2016. 
banyak yaitu pada tahun 2014 mencapai 738.515 jiwa dan pada tahun 2015 mencapai 742.912 jiwa. $^{5}$

Persolan perumahan dan pemukiman di Kabupaten Bone sesungguhnya tidak terlepas dari dinamika sosial dan ekonomi yang berkembang dalam kehidupan masyarakat maupun kebijakan pemerintah setempat. Pengaruh ekonomi seperti harga, suku bunga/margin, pendapatan dan pengaruh non-ekonomi seperti pertambahan penduduk, keamanan dan fasilitas/sarana umum bagian dari faktor banyaknya permintaan terhadap perumahan.

Kondisi di atas sangat menarik dan perlu untuk diteliti karena masih sedikit dan belum banyak ditemukan penelitian ilmiah baik akademis dan praktis. Adapun salah satu penelitian terkait dengan penelitian faktor ekonomi dan non-ekonomi terhadap peningkatan permintaan perumahan dilakukan SMF mengenai analisis faktor-faktor yang mempengaruhi pembelian rumah secara kredit. ${ }^{6}$

Berdasarkan uraian diatas, fokus tulisan ini bagaimana pengaruh faktor ekonomi dan non-ekonomi terhadap peningkatan permintaan perumahan di Kota Watampone.

\section{Teori dan Hukum Permintaan}

Menurut Ibnu Taimiyah, yang dikutip oleh Sayid Syekh, ${ }^{7}$ permintaan suatu barang adalah hasrat terhadap sesuatu yang digambarkan dengan istilah raghabah fi alsyai. Diartikan juga sebagai jumlah suatu barang yang diminta, secara garis besar permintaan dalam ekonomi Islam sama dengan ekonomi konvensional namun ada prinsip-prinsip tertentu yang harus diperhatikan oleh individu muslim dalam keinginannya.

${ }^{5}$ Data BPS Kabupaten Bone.

${ }^{6}$ Tim Riset SMF, Analisis Faktor-Faktor yang Mempengaruhi Pembelian Secara Kredit, www.hfis-smf.co.id (19 Juli 2017).

7 Sayid Syekh, Sekilas Pengantar Ilmu Ekonomi dan Pengantar Ekonomi Islam, (Jakarta: GP Press Group, 2013), hlm. 183. 
Menurut Sadono Sukirno, permintaan adalah keinginan konsumen membeli suatu barang pada berbagai tingkat harga tertentu selama periode waktu tertentu. ${ }^{8}$ Fungsi permintaan seorang konsumen akan suatu barang dirumuskan dibawah ini:

$$
D x=f(Y, P y, T, U)
$$

Dimana :

$$
\begin{aligned}
& \mathrm{Dx}=\text { Jumlah barang yang diminta } \\
& \mathrm{Y}=\text { Pendapatan konsumen } \\
& \mathrm{Py}=\text { Harga barang lain } \\
& \mathrm{T}=\text { Selera } \\
& \mathrm{U}=\text { Faktor-faktor lainnya }
\end{aligned}
$$

Dimana dalam persamaan diatas jumlah barang $\mathrm{X}$ yang diminta dipengaruhi oleh harga barang X, pendapatan kosumen, harga barang lain, selera, dan faktor-faktor lainnya. Dimana DX adalah jumlah barang X yang diminta konsumen, $Y$ adalah pendapatan konsumen, Py adalah harga barang selain $\mathrm{X}, \mathrm{T}$ adalah selera konsumen dan $\mathrm{U}$ adalah faktor-faktor lainnya.

1. Kurva Permintaan

Permintaan konsumen akan suatu barang dipengaruhi oleh harga barang tersebut, dimana setiap perubahan harga barang mempengaruhi keputusan konsumen dalam menentukan berapa jumlah yang akan diminta. Dalam teori permintaan yang terutama dianalisa adalah perkaitan antara diantara permintaan sesuatu barang dengan harga barang tersebut. ${ }^{9}$

Di dalam analisa tersebut dimisalkan "faktor-faktor lain tidak mengalami perubahan, "atau di dalam kata Latin: ceteris paribus. Tetapi dengan permisalan yang dinyatakan ini tidaklah berarti bahwa kita akan mengabaikan faktor-faktor yang dianggap tetap tersebut. Setelah menganalisa perkaitan di antara jumlah permintaan dengan tingkat harga, kita selanjutnya boleh memisalkan bahwa harga adalah tetap dan hlm. 52.

${ }^{8}$ Sadono Sukirno, Pengantar Teori Mikro Ekonomi, (Jakarta : Bima Grafika, 2005), ${ }^{9}$ Ibid., 
kemudian menganalisa bagaimana permintaan sesuatu barang akan dipengaruhi berbagai faktor lainnya. Dibawah ini adalah gambar kurva permintaan :

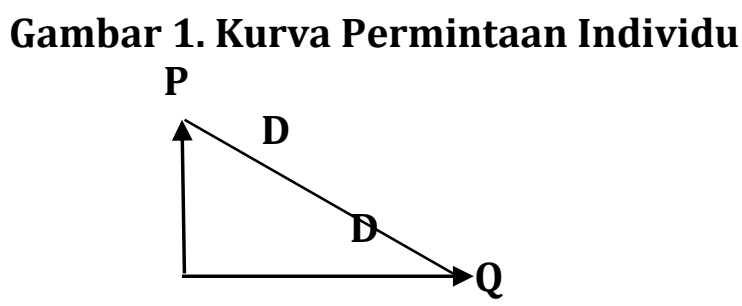

Pada kurva permintaan diatas dapat menjelaskan bahwa tingkat harga suatu barang dengan jumlah barang yang diminta tersebut cateris paribus. ${ }^{10}$ Dari gambar 1 di atas menggambarkan antara jumlah yang diminta dengan permintaan, dimana dalam perubahan harga dapat mempengaruhi jumlah barang yang diminta tetapi bukan permintaan sedangkan perubahan permintaan menyebabkan kurva permintaan bergeser ke kanan dan ke kiri.

Jadi dalam kurva permintaan menjelaskan bahwa jika slope menurun ke kanan mengartikan bahwa harga barang naik (asumsi yang lain tetap cateris paribus) maka akan cenderung konsumen akan menurunkan permintaan atas barang tersebut. ${ }^{11}$

2. Hukum Permintaan

Hukum permintaan merupakan pernyataan dengan menganggap hal lainnya sama atau konstan dimana kuantitas atau jumlah barang akan turun ketika harga suatu barang meningkat. ${ }^{12}$

Menurut Sukirno hukum permintaan menjelaskan sifat perkaitan di antara permintaan sesuatu barang dengan harganya. Hukum permintaan pada hakekatnya merupakan sesuatu hipotesis yang

\footnotetext{
${ }^{10}$ Dominick Salvatore, Mikro Ekonomi, Edisi Keempat, (Jakarta: Penerbit Erlangga, 2006), hlm. 12

${ }^{11}$ Jaka Wasana M., Kirbrandoko, Pengantar Mikro Ekonomi, (Jakarta: Penerbit Erlangga, 1987), hlm. 64

12 Gregory Mankiw, Pengantar Ekonomi, Edisi kedua, (Jakarta: Penerbit Erlangga, 2003), hlm. 101
} 
menyatakan: makin rendah harga dari suatu barang, makin banyak permintaan ke atas barang tersebut; sebaliknya makin tinggi harga sesuatu barang, makin sedikit permintaan ke atas barang tersebut. ${ }^{13}$

Permintaan dan harga mempunyai sifat keterkaitan yang negatif karena disebabkan oleh :

a. Kenaikan harga menyebabkan seorang konsumen mencari barang substitusi yang sama sehingga barang substitusi tersebut permintaannya meningkat sedangkan barang yang utama permintaannya menurun.

b. Dengan kenaikan harga maka dapat mempengaruhi pendapatan riil konsumen sehingga konsumen akan menurunkan atau mengurangi permintaan.

Menurut Sukirno, permintaan suatu barang dipasar akan terjadi apabila konsumen mempunyai keinginan (willing) dan kemampuan (ability) untuk membeli, dimana akan terjadinya permintaan jika konsumen sudah memiliki keinginan dan kemampuan. Jadi jika konsumen hanya memiliki salah satu antara keinginan atau kemampuan saja maka permintaan akan barang belum terjadi. ${ }^{14}$

3. Permintaan Pasar

Permintaan pasar merupakan jumlah total suatu barang yang ingin dibeli oleh setiap konsumen pada setiap tingkat harga. Permintaan individual adalah jumlah suatu barang yang dibeli oleh konsumen pada setiap tingkat harga. ${ }^{15}$

$$
\begin{aligned}
\text { Permintaan pasar } & =\mathrm{f}(\text { Px,li }) \\
& =\mathrm{f}(\mathrm{Px}, \mathrm{Ia})+\mathrm{Fb}(\mathrm{Px}, \mathrm{lb}) \\
& =\mathrm{a} \mathrm{fi}(\mathrm{Px}, \mathrm{li})
\end{aligned}
$$

Dimana Px adalah harga barang $\mathrm{x}$,

\footnotetext{
13 Sadono Sukirno, Mikro Ekonomi Teori Pengantar, Edisi Ketiga, (Jakarta: PT. Raja Grafindo Persada, 2003), hlm. 76

${ }^{14}$ Sadono Sukirno, Mikro Ekonomi Teori Pengantar, Edisi Ketiga, (Jakarta: PT. Raja Grafindo Persada, 2003), hlm. 89

15 Suryawati, Teori Ekonomi Mikro, (Yogyakarta: UPP AMP YKPN, 2005), hlm. 15
} 
Ia adalah pendapatan konsumen $\mathrm{A}$,

Ib adalah pendapatan konsumen B.

4. Elastisitas (sensitivitas) Permintaan

Menurut Miller dan minner, ${ }^{16}$ secara teori ekonomi dikenal istilah elastisitas harga permintaan (price elasticity of demand) sebagai suatu konsep yang menghubungkan perubahan kuantitas pembelian/ permintaan optimalatas suatu komoditi dengan perubahan harga relatifnya.

Menurut Sukirno, ${ }^{17}$ dalam pengukuran elastisitas permintaan kerap dinyatakan dalam ukuran koefisien elastisitas permintaan. Koefisien permintaan merupakan ukuran perbandingan persentase perubahan harga atas barang tersebut. Koefisien elastisitas permintaan dapat di rumuskan sebagai berikut :

a. Elastisitas

Barang dikatakan elastis sempurna bila kurva permintaan mempunyai koefisien elastisitas lebih besar daripada satu. Hal ini terjadi bila jumlah barang yang diminta lebih besar daripada persentase perubahan harga barang tersebut.

b. Elastisitas Uniter

Barang dikatakan elastis uniter bila kurva permintaan mempunyai koefisien elastisitas lebih besar daripada satu. Hal ini terjadi bila jumlah barang yang diminta lebih besar daripada persentase perubahan harga barang direspon secara proporsional terhadap persentase jumlah barang yang diminta.

c. Tidak Elastis

${ }^{16}$ Roger Le Roy Miller, Roger E. Meiners, Teori Ekonomi Intermediate, Terj. Hans Munandar, (Jakarta: PT. Raja Grafindo Persada, 2000), hlm. 111

17 Sadono Sukirno, Pengantar Teori Mikro Ekonomi, (Jakarta: PT. Raja Grafindo Persada, 2003), hlm. 102, lihat, Amshari, M. M. (2019). Analisis Biaya Dan Efisiensi Produksi Dalam Ekonomi Islam. BALANCA: Jurnal Ekonomi dan Bisnis Islam, 1(1), 133-148. 
Barang dikatakan tidak elastis bila persentase perubahan jumlah yang diminta lebih kecil daripada persentase perubahan harga sehingga koefisien elastisitas permintaannya antara nol dan satu.

\section{Gambar 2. Jenis-Jenis Elastisitas Permintaan}

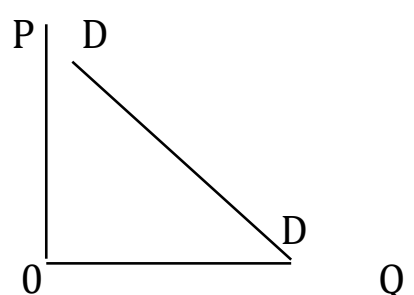

1. Elastisitas $\mathrm{E}>1$

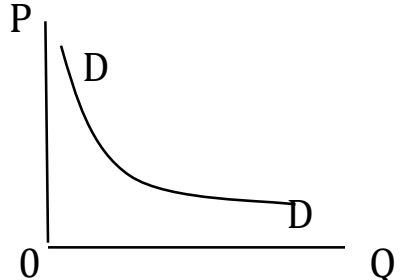

2. Elastis Uniter $\mathrm{E}=1$

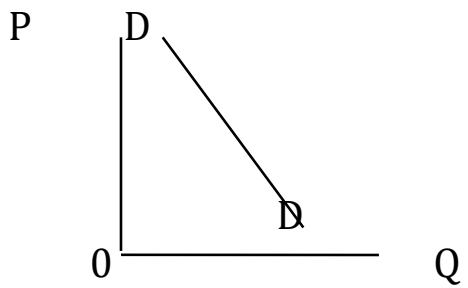

3. Tidak Elastis $\mathrm{E}<1$

Menurut Sukirno, ${ }^{18}$ terdapat beberapa faktor yang mempengaruhi elastisitas permintaan suatu barang, yaitu :

1) Tingkat kemampuan barang-barang lain untuk menggantikan barang yang bersangkutan.

2) Persentase pendapatan yang akan dibelanjakan untuk membeli barang itu.

3) Jangka waktu pengamatan atas permintaan.

Pengukuran kuantitatif besarnya respon perubahan permintaan akibat adanya perubahan faktor-faktor yang mempengaruhi permintaan konsumen terhadap suatu barang disebut dengan elastisitas. Sehingga rumus elastisitas secara umum dapat dinyatakan dengan :

18 Sadono Sukirno, Pengantar Teori Mikro Ekonomi, (Jakarta: PT. Raja Grafindo Persada, 2003), hlm. 111 


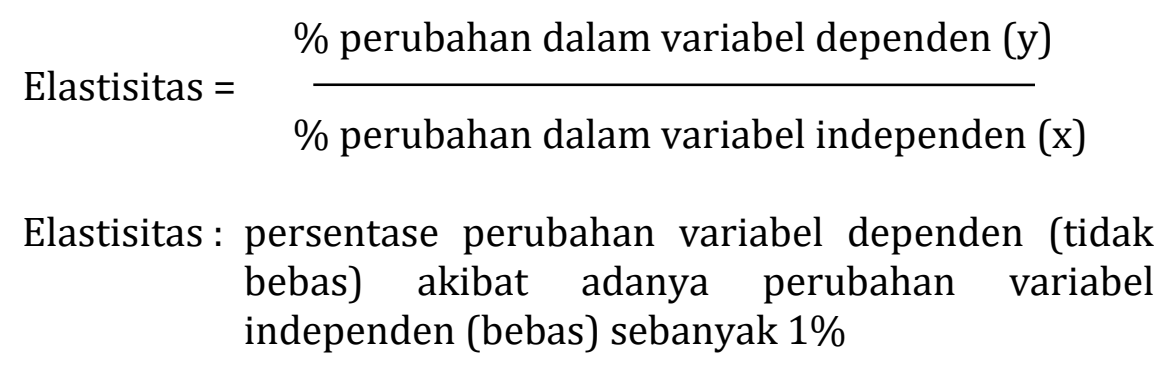

Sensitivitas/elastisitas dapat diukur dengan dua cara yang berbeda yaitu disebut elastisitas titik (point elasticity) dan elastisitas busur (arch elasticity). Konsep elastisitas titik digunakan untuk mengukur pengaruh perubahan yang sangat kecil (marginal) dalam variabel independen $\mathrm{X}$ terhadap perubahan variabel dependen $\mathrm{Y}$.

Konsep elastisitas busur (Arch Elasticity), berdasarkan pada kenyataan yang ada bahwa elastisitas umumnya tidak konstan, melainkan berbeda-beda diberbagai titik disepanjang (kurva) fungsi permintaan tertentu. Untuk mengatasi masalah elastisitas yang berubah-ubah disepanjang kurva permintaan, maka digunakan "elastisitas busur" yang menghitung elastisitas rata-rata.

Untuk mengetahui sampai sejauh mana respon suatu permintaan terhadap perubahan harga, digunakan suatu pengukuran kuantitatif yang dinamakan "(Price Elastisitas of Demand)" elastisitas harga permintaan yang mengukur besarnya persentase perubahan jumlah barang yang diminta perpriode waktu akibat adanya suatu persentase perubahan harga, dengan menganggap variabel independen lainnya dalam fungsi permintaan konstan.

5. Faktor-Faktor Yang Mempengaruhi Permintaan

Menurut Suyawati, ${ }^{19}$ ada beberapa faktor yang menyebabkan mengapa suatu permintaan konsumen terhadap suatu barang berubah:

a. Harga barang itu berubah sedang faktor yang lain tetap perubahan ini hanya menyebabkan pergerakan di sepanjang kurva permintaan.

${ }^{19}$ Suryawati, Teori Ekonomi Mikro, (Yogyakarta: UPP AMP YKPN, 2005), hlm. 15 
b. Salah satu atau lebih faktor-faktor lain berubah (tidak ada lagi ceteris paribus). Perubahan ini menyebabkan terjadi pergeseran seluruh kurva permintaan.

Perubahan ini menyebabkan terjadi pergeseran seluruh kurva permintaan. Kenaikan permintaan akan menyebabkan kurva permintaan bergerak naik ke kanan. Sebaliknya jika permintaan turun maka kurva permintaan akan bergeser turun ke kiri.

Adapun faktor-faktor pembentuk keadaan ceteris paribus adalah:

1) Pendapatan

Bila pendapatan konsumen naik maka permintaan akan naik dan sebaliknya, namun untuk kasus barang inferior peningkatan pendapatan justru akan mengurangi permintaan suatu barang.

2) Jumlah konsumen di pasar

Peningkatan konsumen akan meningkatkan permintaan suatu barang di pasar.

3) Selera atau preferensi konsumen

Bila selera konsumen terhadap suatu barang naik, maka kurva permintaan akan bergeser ke kanan, yang berarti di setiap tingkat harga konsumen akan menambah konsumsinya.

Harga barang lain yang terkait, yaitu :

1) Jika barang lain yang merupakan barang substitusi. Bila harga barang substitusi, misalnya harga gandum turun, maka permintaan beras menurun (kurva permintaan bergeser ke kiri).

2) Jika barang lain merupakan barang komplementer. Misalnya, jika harga gula naik, maka permintaan kopi akan turun (kurva permintaan bergeser ke kiri).

Gambar 3. Kurva Permintaan Pasar 


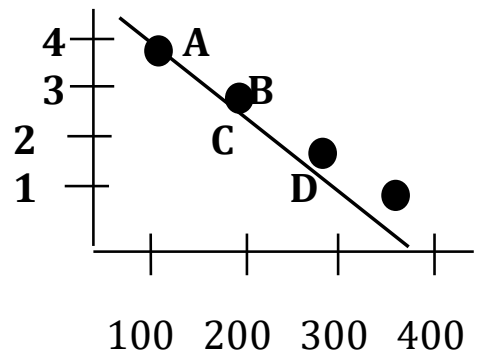

Sumber: Roger Le Roy, Miller \& Roger E, Meiners, Intermediate Economics Theory, 1986

Menurut Imamul Arifin, disamping harga barang, ada beberapa faktor yang mempengaruhi tingkat permintaan masyarakat terhadap barang dan jasa. Faktor-faktor tersebut adalah pendapatan konsumen, harga barang lain, ukuran pasar, selera dan ekspektasi. ${ }^{20}$

Adapun faktor-faktor lain yang dapat mempengaruhi permintaan terhadap barang dan jasa adalah faktor non-ekonomi seperti hubungan sosial, budaya dan politik. Menurut Awang Firdaos bahwa permintaan konsumen terhadap perumahan dipengaruhi beberapa faktor yaitu lokasi, pertambahan penduduk, pendapatan konsumen, kemudahan mendapat pinjaman, fasilitas \& sarana umum, harga pasar rumah dan peraturan perundangan. ${ }^{21}$

\section{Permintaan Pasar Perumahan.}

Permintaan akan rumah memainkan peranan penting dalam mempengaruhi nilai pasar properti jenis perumahan. Hal ini disebabkan penawaran tanah untuk pembangunan terbatas dari segi keluasaan akan tetapi dari segi permintaan selalu berubah dan bertambah. Menurut Eckert,

20 Imamul Arifin, Membuka Cakrawala Ekonomi, (Bandung: PT. Setia Purna Inves, 2007), hlm. 40

21 Awang Firdaus, Permintaan dan Penawaran perumahan, Vol. 007, (Jakarta: Valuestate, 1997), hlm. 14. 
faktor-faktor yang sangat penting dan berpengaruh terhadap permintaan pasar perumahan yaitu:22

1. Faktor ekonomi, perubahan faktor ekonomi yang mempengaruhi permintaan perumahan adalah pendapatan, tingkat bunga, kebijakan pinjaman, tingkat sewa dan harga rumah.

2. Faktor sosial adalah kepadatan penduduk, ukuran keluarga, pendidikan, tingkat kejahatan dan distribusi umur.

3. Faktor pemerintahan, pelayanan pemerintahan kota dan tingkat pajak masyarakat.

4. Faktor lingkungan, perubahan faktor lingkungan yang berpengaruh terhadap permintaan perumahan adalah topografi, bentuk lahan, kondisi tanah, dan kemudahan fasilitas seperti berikut : parkir, pusat perbelanjaan, sekolah, tempat ibadah, kesempatan kerja, transportasi, dan pelayanan ijin-ijin pendirian usaha.

Pilihan lokasi untuk rumah tinggal menggambarkan suatu usaha individu untuk menyeimbangkan dua pilihan yang bertentangan, yaitu kemudhan ke pusat kota dan luas tanah yang bisa diperoleh. Menurut Synder dan Anthony ada beberapa kriteria yang harus diperhatikan dalam pemilihan lokasi perumahan: ${ }^{23}$

1. Perwilayahan (zoning). Peraturan antara lain terkait dengan tipe dan ukuran bangunan, persyaratan ketinggian bangunan, garis sepadan bangunan.

2. Utilitas (utilities). Meliputi ketersediaan dan kondisi saluran pembuangan air hujan, sanitasi, pemasangan gas, listrik, dan telepon.

3. Faktor-faktor teknis (technical factor). Kondisi tanah, topografi, dan drainase, desain dan biaya.

22 Wahyu Hamidi, Muhammad Hasbi, "Analisis Pengaruh Migrasi Masuk Terhadap Permintaan Rumah Sederhana Di Kota Pekanbaru", Jurnal Ekonomi, Nomor 03, Vol. 22, Hlm. 11

${ }^{23}$ Anthony J. Catanesa, James C Snyder, Perencanaan Kota, (Jakarta: Penerbit Erlangga, 1991), hlm. 153 
4. Lokasi (location). Ketersediaan di pasar untuk penggunaan yang diusulkan, aksesibilitas, kondisi sekitaran, dan kondisi lalu lintas.

5. Estetika (eisthetics). Meliputi pemandangan dan bentang alam yang ada.

6. Komunitas (community). Terutama terkait lingkungan termasuk di dalamnya kesehatan dan jasa-jasa yang diselenggarakan pemerintah.

7. Pelayanan kota (city service). Penyediaan pendidikan, layanan kesehatan, dan jasa-jasa yang diselenggarakan pemerintah.

8. Biaya (cost). Biaya dan keterjangkauan penyewa.

Disamping itu Awang Firdaus menjelaskan bahwa permintaan konsumen terhadap perumahan dipengaruhi oleh faktor-faktor sebagai berikut : 24

1. Lokasi

Keberadaan lokasi perumahan, apakah dipusat di pinggir kota sangat mempengaruhi minat konsumen dalam membeli rumah. Semakin strategis letak perumahan tersebut berarti semakin baik dan memiliki tingkat permintaan yang semakin tinggi. Faktor-faktor ekonomi dari keberadaan lokasi perumahan juga menjadi pertimbangan konsumen dalam memilih rumah yang dikehendakinya. Jarak menuju tempat kerja, tempat hiburan, dan fasilitas umum sebagai motif efesiensi waktu dan biaya transportasi merupakan faktor ekonomi yang menjadi pertimbangan konsumen didalam memilih lokasi rumah yang dimaksud.

2. Pertambahan penduduk

Dengan alasan bahwa setiap orang memerlukan tempat tinggal sebagai tempat berlindung, maka setiap pertambahan penduduk baik secara alami maupun non-alami (karena urbanisasi) akan meningkatkan permintaanakan rumah.

3. Pendapatan Konsumen

24 Awang Firdaus, Permintaan dan Penawaran Perumahan, Vol. 007, (Jakarta: Valuestate, 1997), hlm. 14 
Kesanggupan seseorang di dalam memiliki rumah sangat dipengaruhi pendapatan yang diperolehnya. Apabila pendapatan seseorang meningkatdan kondisi perekonomian tidak terjadi resesi dan inflasi, kecenderungan untuk memiliki rumah akan meningkat baik secara kualitas maupun kuantitas.

4. Kemudahan Mendapatkan Pinjaman

Pada pasar properti perumahan, permintaan perumahan dipengaruhi juga oleh kebijakan pemerintah dan institusi keuangan seperti perbankan. Karakteristik pasar properti yaitu membutuhkan dana besar, menyebabkan konsumen sangat tergantung pada kemudahan pendanaan. Kemudahan pendanaan ini dapat berupa fasilitas kredit pinjaman, penurunan tingkat suku bunga pinjaman, dan jangka waktu pelunasan pinjaman. Apabila kemudahan tersebut dapat diperoleh konsumen, dipercaya permintaan akan rumah oleh konsumen akan bertambah. Sebaliknya jika syarat mendapatkan pinjaman sangat ketat, atau suku bunga pinjaman yang tinggi akan menurunkan permintaan rumah oleh masyarakat.

5. Fasilitas dan Sarana Umum

Fasilitas disini meliputi fasilitas umum dan fasilitas sosial, diantaranya infrastruktur, sarana pendidikan, kesehatan, keagamaan, sarana transportasi, dan lain-lain. Keberadaan fasilitas tersebut membangun serta menarik minta investor yang selanjutnya akan meningkatkan permintaan akan rumah di kawasan tersebut.

6. Harga Pasar Rumah

Seperti dalam hal teori permintaan dan penawaran, semakin tinggi harga barang akan mengakibatkan penurunan permintaan akan barang yang dimaksud. Apabila harga rumah menengah naik, sementara kecenderungan memiliki rumah dengan tingkat harga tersebut akan berkurang dan permintaan akan beralih ke rumah dengan harga yang lebih rendah.

7. Undang-undang 
Peraturan tentang jenis hak penggunaan lahan/tanah yang membatasi hak atas tanah tersebut turut menjadi faktor yang mempengaruhi permintaan konsumen akan rumah. Demikian juga dengan peraturan lain seperti peraturan perpajakan (PBB dan BPHTB) turut menjadi faktor yang menjadi pertimbangan konsumen dalam membeli rumah.

\section{Analisis Kebutuhan Perumahan}

Perumahan adalah kumpulan rumah sebagai bagian dari pemukiman, baik perkotaan maupun pedesaan yang dilengkapi dengan prasarana, sarana, dan utilitas umum sebagai hasil upaya pemenuhan rumah yang layak huni. ${ }^{25}$ Sedangkan permukiman adalah bagian dari lingkungan hunian yang terdiri atas lebih dari satu satuan perumahan yang mempunyai prasarana, sarana, utilitas umum, serta mempunyai penunjang kegiatan fungsi lain di kawasan perkotaan atau kawasan pedesaan. ${ }^{26}$

Berdasarkan hasil regresi hasil persamaan regresi yang didapatkan, $Y=4,453+0,53, X 1,-0,06 X 2,+0,16 X 3+0,24 X 4+0,43$ X5 + 0,33 X6. Adapun variabel yang berpengaruh secara signifikan terhadap permintaan perumahan di Kota Watampone antara lain yaitu variabel jumlah anggota keluarga, lokasi dan lingkungan. Sedangkan variabel yang tidak signifikan berpengaruh terhadap permintaan perumahan di Kota Watampone adalah harga, pendapatan, dan harga tipe lain.

Tabel 2. Hasil Analisis Regresi Berganda Faktor-Faktor Ekonomi Dan Non-Ekonomi Yang Mempengaruhi Permintaan Perumahan di Kota Watampone

\begin{tabular}{|l|l|l|l|l|l|}
\hline $\begin{array}{l}\text { Variabel } \\
\text { Dependen }\end{array}$ & $\begin{array}{l}\text { Variabel } \\
\text { Independen }\end{array}$ & $\begin{array}{l}\text { Koefisien } \\
\text { Regresi }\end{array}$ & $\begin{array}{l}\text { T- } \\
\text { stat }\end{array}$ & Sig & Status \\
\hline ๑ $\odot$ & Harga (X1) & 0,53 & 0,518 & 0,606 & Tidak \\
\hline
\end{tabular}

25 Undang-Undang Republik Indonesia No.1 Tahun 2011, Tentang Perumahan dan Kawasan Permukiman, pasal 1, hlm. 3.

26 Ibid., 


\begin{tabular}{|c|c|c|c|c|c|}
\hline & & & & & Signifikan \\
\hline & Pendapatan(X2) & 0,06 & $\begin{array}{l}- \\
0,229\end{array}$ & 0,820 & $\begin{array}{l}\text { Tidak } \\
\text { Signifikan }\end{array}$ \\
\hline & $\begin{array}{l}\text { Harga Tipe Lain } \\
\text { (X3) }\end{array}$ & 0,16 & 1.351 & 0,180 & $\begin{array}{l}\text { Tidak } \\
\text { Signifikan }\end{array}$ \\
\hline & $\begin{array}{l}\text { Jumlah Anggota } \\
\text { Keluarga (X4) }\end{array}$ & 0,24 & 2.244 & 0,027 & Signifikan \\
\hline & Lokasi (X5) & 0,43 & 5.273 & 0,000 & Signifikan \\
\hline & $\begin{array}{l}\text { Lingkungan } \\
\text { (X6) }\end{array}$ & 0,33 & 3.915 & 0,000 & Signifikan \\
\hline Kofisien Ko & nstan & 4,453 & F-Stat & stik & 29,485 \\
\hline Sig. (kosnta & nta) & 0,005 & $\begin{array}{l}\text { Sig. } \\
\text { (F.Sta }\end{array}$ & stik) & 0,000 \\
\hline Observasi & & 102 & & & \\
\hline
\end{tabular}

Sumber: Data Primer Diolah 2018

1. Harga (X1)

Hasil analisis regresi menunjukan bahwa variabel Harga $(t=518$, $p=0,606)$ tidak berpengaruh secara signifikan akan tetapi berhubungan positif $(\mathrm{t}=518)$ terhadap peningkatan permintaan perumahan. Hal ini disebabkan karena kebutuhan terhadap rumah huni merupakan kebutuhan primer yang sangat mendesak sehingga masyarakat tidak terlalu mempermasalahkan dari segi harga. Hal ini sejalan dengan penelitian yang dilakukan oleh Muhammad Taufiq dan Eduardus Tandelin yang menyatakan hubungan harga rumah dengan permintaan terhadap rumah menunjukkan bahwa harga rumah mempunyai pengaruh negatif terhadap permintaan rumah. ${ }^{27}$

2. Pendapatan (X2)

${ }^{27}$ Muhammad Taufiq \& Eduardus Tandelilin, "Faktor-Faktor yang Mempengaruhi Transaksi Rumah sederhana Tipe 36 di kabupaten Boyolali Provinsi Jawa-Tengah", Jurnal Ekonomi Bisnis, Yogyakarta: Penerbit UGM, 2007, hlm. 43 
Hasil analisis regresi menunjukan bahwa variabel Pendapatan $(\mathrm{t}=$ -229, $\mathrm{p}=0,820$ ) tidak berpengaruh secara signifikan, bahwa berhubungan negatif $(\mathrm{t}=-229)$ terhadap peningkatan permintaan perumahan. Hal ini menunjukan variabel Harga yang ditawarkan developer kepada masyarakat tidak berpengaruh terhadap peningkatan permintaan perumahan di kota Watampone. Hal ini sejalan dengan penelitian yang dilakukan oleh Ika Rahayu dengan judul Analisis FaktorFaktor yang Mempengaruhi Konsumen Melakukan Pembelian Rumah pada Crown Property Agency Medan yang menyatakan hubungan pendapatan dengan permintaan terhadap rumah, menunjukkan nilai negatif pada koefisien variabel pendapatan yang akan menurunkan pembelian rumah pada Crown Property Agency Medan. ${ }^{28}$

3. Harga Tipe Lain (X3)

Hasil analisis regresi menunjukan bahwa variabel Harga Tipe lain $(\mathrm{p}=1.351, \mathrm{p}=0,180)$ tidak berpengaruh secara signifikan, bahwa berhubungan positif $(\mathrm{p}=1.351)$ terhadap peningkatan permintaan perumahan. Hal ini menunjukan bahwa variabel harga tipe lain yang ditawarkan developer kepada masyarakat tidak memiliki pengaruh terhadap peningkatan permintaan perumahan di kota Watampone. Hal ini disebabkan dalam pengambilan keputusan, para konsumen tidak sepenuhnya mementingkan masalah harga karena rumah merupakan kebutuhan primer yang harus segera dipenuhi mengingat jumlah keluarga yang terus bertambah.

Hal ini sejalan dengan penelitian yang dilakukan oleh Sishadiyati yang menyatakan hubungan harga rata-rata rumah lain tidak berpengaruh nyata (signifikan) terhadap permintaan kredit rumah. Keadaan ini dikarenakan memiliki rumah sebagai tempat tinggal merupakan dambaan setiap keluarga dan juga bisa sebagai investasi

${ }^{28}$ Ika Rahayu, "Analisis Faktor-Faktor Yang Mempengaruhi Konsumen Melakukan Pembelian Rumah Pada Crown Property Agency Medan", Jurnal Fakultas Ekonomi Universitas Sumatera Utara, Medan: USU Repository, 2007, hlm. 30 
jangka panjang, mengingat jumlah keluarga yang terus bertambah. Kebutuhan akan rumah masih akan terus meningkat meskipun harga rata-rata rumah tinggi masyarakat tetap membutuhkan rumah. ${ }^{29}$

4. Jumlah Anggota Keluarga (X4)

Hasil analisis regresi menunjukan bahwa variabel Jumlah anggota keluarga $(p=2.244, p=0,027)$ berpengaruh secara signifikan, bahwa berhubungan positif $(\mathrm{p}=0,027)$ terhadap peningkatan permintaan perumahan. Hal ini menunjukan variabel Jumlah anggota keluarga yang ditawarkan developer kepada masyarakat berpengaruh terhadap peningkatan permintaan perumahan di kota Watampone.

Hal ini sejalan dengan penelitian yang dilakukan oleh Yulya Citra Sutra Syah yang menyatakan keluarga berpengaruh positif dan signifikan terhadap keputusan pembelian perumahan. Semakin tinggi tingkat kesesuaian antara produk dan jumlah keluarga akan semakin tinggi keputusan pembelian konsumen. ${ }^{30}$ Sejalan dengan penelitian Stefandy, Vecky, dan Audie yang menyatakan jumlah penduduk berpengaruh positif sebagaimana dasar teori, semakin tinggi jumlah penduduk, maka semakin tinggi pula permintaan perumahan. ${ }^{31}$

5. Lokasi (X5)

Hasil analisis regresi menunjukan bahwa variabel Lokasi $(\mathrm{p}=$ $5,273, p=0,000$ ) berpengaruh secara signifikan bahwa berhubungan positif $(p=5,273)$ dengan peningkatan permintaan perumahan. Hal ini menunjukan variabel lokasi yang ditawarkan developer kepada masyarakat berpengaruh terhadap peningkatan permintaan perumahan di kota Watampone.

${ }^{29}$ Sishadiayati, "Analisis Faktor-Faktor yang Mempengaruhi Permintaan Kredit Kepemilikan Rumah Tipe 36 Pada Bank Tabungan Negara (BTN) di Surabaya”, Jurnal Ilmu Ekonomi Pembangunan, 2014, hlm. 233

30 Yulya Citra Sutra Syah, "Pengaruh Produk, harga, dan Lokasi Terhadap Keputusan Pembelian Prumahan diKota Padang dengan Keluarga Sebagai Variabel Pemoderasi (Studi Kasus Pada PT. Hati Prima Griya Elok), Jurnal Sains Manajemen UBH, 2015, hlm. 13

${ }^{31}$ Stefandy dkk., "Analisis Pengaruh Pendapatan Perkapita dan Jumlah Penduduk Terhadap Permintaan Perumah di Kota Manado Tahun 2003-2012", Jurnal Berkala Ilmiah Efisiensi, Vol.4 No.3, 2014, hlm. 10 
Hal ini sejalan dengan penelitian Ismi Mahardini dan Woyanti, yang menyatakan bahwa lokasi mempengaruhi permintaan perumahan karena yang menjadi pertimbangan bagi konsumen dalam membeli rumah adalah lokasi, lokasi yang nyaman dan tenang menjadi pilihan konsumen untuk membeli perumahan. ${ }^{32}$ Sejalan dengan penelitian Brahmanto, yang menyatakan bahwa lokasi menjadi faktor penting yang mempengaruhi permintaan perumahan karena lokasi yang strategis akan mendorong seseorang untuk membeli perumahan di lokasi tersebut. 33

6. Lingkungan (X6)

Hasil analisis regresi menunjukan bahwa variabel Lokasi $(\mathrm{p}=$ $3,915, p=0,000$ ) berpengaruh secara signifikan bahwa berhubungan positif $(p=3,913)$ dengan peningkatan permintaan perumahan. Hal ini menunjukan variabel Lingkungan yang ditawarkan developer kepada masyarakat berpengaruh terhadap peningkatan permintaan perumahan di kota Watampone.

dengan penelitian yang dilaksanakan oleh Abdur Rahman Haris yang menyatakan terdapat pengaruh lingkungan terhadap keputusan pembelian rumah. Semakin baik lingkungan maka tingkat keputusan pembelian konsumen akan tinggi, sebaliknya semakin tidak baik lingkungan maka tingkat keputusan pembelian konsumen akan rendah. ${ }^{34}$

Permintaan adalah keinginan akan sesuatu produk yang didukung dengan kemampuan serta ketersediaan membelinya. Jadi, keinginan menjadi permintaan bila didukung oleh daya beli. Tingkatan kebutuhan manusia dapat dijabarkan pada gambar dibawah ini: ${ }^{35}$

32 Ismi Mahardini dan Woyanti, N., "Analisis Pengaruh Harga, Pendapatan, Lokasi, dan Fasilitas terhadap Permintaan Rumah Sederhana". Diponegoro Journal of Economics. Vol.1 No.1, 2012, hlm. 11

${ }^{34}$ Brimanto, Y, Pengaruh Karakteristik Pembeli Terhadap Pertimbangan Pembelian Unit Rumahdi Perumahan Graha Famili, Jurnal Ekonomi Bisnis, Surabaya, 2009, hlm. 10.

35 Philip Kotler, Susanto., Manajemen Pemasaran di Indonesia, (Jakarta: Salemba Empat, 1999), hlm. 240 


\section{Gambar 4. Hirarki Kebutuhan Maslow}

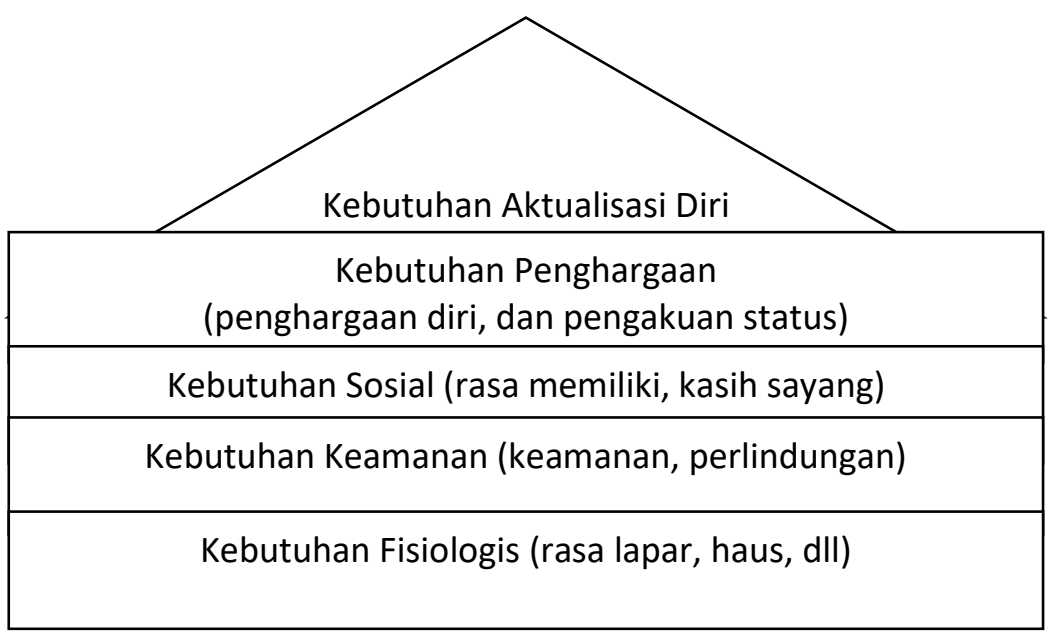

Sumber: Kotler dan Susanto (1999)

Dalam pengambilan keputusan, pengaruh lingkungan, perbedaan dan pengaruh individu, serta proses psikologis dapat membentuk dan mempengaruhi keputusan konsumen mencakup semua jenis perilaku pemenuhan kebutuhan dan jajaran luas dari faktor yang memotivasi dan mempengaruhinya. Secara sistematik model dasar dari proses keputusan konsumen beserta faktor yang mempengaruhi dan membentuk perilaku tersebut dapat dijelaskan pada gambar berikut: ${ }^{36}$

\section{Gambar 5. Model Perilaku Pengambilan Keputusan Konsumen dan Faktor-Faktor yang Mempengaruhinya}

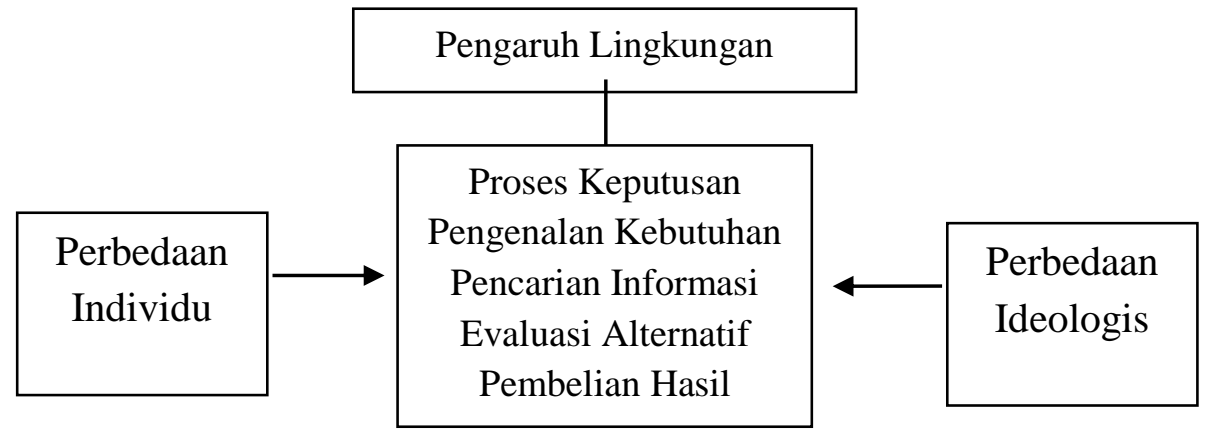

Sumber : Engel, et. Al (1994) hlm. 126

36 Well Engel, Miniard., Perilaku Konsumen, Jilid 1, (Jakarta: Binarupa Aksara, 1994), 
Secara umum keputusan konsumen mengambil bentuk dan mempunyai langkah- langkah sebagai berikut:

1. Pengenalan kebutuhan, yaitu konsumen mempresepsikan perbedaan antara keadaan yang diinginkan dengan kondisi aktual untuk membangkitkan dan mengaktifkan proses keputusan. Kebutuhan ini akan menjadi motivasi dalam membuat keputusan.

2. Pencarian informasi, yaitu konsumen mencari informasi yang disimpan dalam ingatan atau mendapatkan informasi yang relevan dari lingkungan.

3. Evaluasi alternatif, yaitu konsumen mengevaluasi pilihan terkait dengan manfaat yang diharapkan dan menyempitkan pilihan. Konsumen menggunakan informasi yang tersimpan dalam ingatan ditambah informasi yang didapat dari luar untuk membangun kriteria tertentu. Ini membantu konsumen untuk mengevaluasi dan membandingkan alternatif tersebut.

4. Pembelian, yaitu konsumen memperoleh alternatif yang dipilih atau pengganti yang dapat diterima bila perlu. Konsumen dapat memutuskan apakah produk yang akan dibeli atau diputuskan untuk tidak dibeli sama sekali.

5. Hasil, yaitu perilaku konsumen setelah pembelian dimana konsumen mengevaluasi alternatif setelah pembelian. Bukan tidak lazim pembeli akan mengalami periode yang seketika dan sementara berupa penyesalan atau keraguan setelah keputusan pembelian. Hal ini dapat menimbulkan dampak apakah pembeli terpuaskan atau tidak.

\section{Penutup}

Hasil penelitian ini menunjukkan faktor non-ekonomi memiliki pengaruh positif dan signifikan terhadap peningkatan permintaan perumahan di Kota Watampone adalah variabel jumlah anggota keluarga, lokasi, dan lingkungan. Sedangkan faktor ekonomi tidak signifikan 
berpengaruh terhadap permintaan perumahan di kota Watampone. Selanjutnya faktor non-ekonomi yang berpengaruh paling besar terhadap peningkatan permintaan perumahan di kota Watampone adalah variabel jumlah anggota keluarga, lokasi, lingkungan. Hal ini dapat dilihat dengan nilai probabilitas (signifikansi) sebesar 0,000. Kemudian diikuti oleh variabel jumlah anggota keluarga dengan nilai probabilitas (signifikansi) sebesar 0,027 .

Allah SWT telah menetapkan agar manusia dapat mencapai kebutuhan maslahâh dalam hidupnya yaitu perlindungan terhadap agama, jiwa, akal, kehormatan/keturunan dan harta. ${ }^{37}$ Maka pembangunan perumahan (pemukiman) disamping sebagai bentuk ibadah muamalah juga harus mencapai tujuan-tujuan tersebut. Artinya sebuah pemukiman (rumah, lingkungan dan fasilitas) harus mendukung terwujudnya tujuan-tujuan tersebut.

Kebutuhan manusia adalah keadaan merasa tidak memiliki kepuasandasar. Kebutuhan ini tidak diciptakan oleh masyarakat, namun sudah ada terukir dalam hayati serta kondisi manusia. Sedangkan keinginan adalah hasrat akan pemuas tertentu dari kebutuhan tersebut. Bila seseorang berhasil dalam memuaskan suatu kebutuhan yang penting. Kebutuhan itu tidak lagi menjadi motivator, dia akan berusaha untuk memenuhi kebutuhan yang lebih rendah tingkat kepentingannya.

\section{Daftar Pustaka}

Arifin, Imamul, Membuka Cakrawala Ekonomi, (Bandung: PT. Setia Purna Inves, 2007).

Awang Firdaus, Permintaan dan Penawaran perumahan, Vol. 007, (Jakarta: Valuestate, 1997).

Awang Firdaus, Permintaan dan Penawaran Perumahan, Jakarta: Valuestate Vol. 007/1997.

${ }^{37}$ Abū Ishâq Ibrâhim Asyâtibi, al-Muwâfaqât fi Usūl asyarīah, Jilid I, Juz 2, (Beirut: Dar al-Kutub al-'ilmiyyah), hlm. 7-13. 
Dominick Salvatore, Mikro Ekonomi, Edisi Keempat, (Jakarta: Penerbit Erlangga, 2006).

Firdaus, Awang, Permintaan dan Penawaran perumahan, Vol. 007, (Jakarta: Valuestate, 1997).

Panudju, Pengadaan Perumahan Perkotaan dengan Peran Serta Masyarakat Berpenghasilan Rendah, (Bandung: Alumni, 1999).

Gay \& L.R., Diehl Research Methods for Business and Management, (New York, MacMillan Publishing Company, 1992).

Ibrâhim asyâtibi, Abū Ishâq, al-Muwâfaqât fi Usūl asyarīah, Jilid I, Juz 2, (Beirut: Dar al-kutub al-'ilmiyyah).

James C Snyder, Anthony J. Catanesa, Perencanaan Kota, (Jakarta: Penerbit Erlangga, 1991).

Muhammad Hasbi,Wahyu Hamidi, "Analisis Pengaruh Migrasi Masuk Terhadap Permintaan Rumah Sederhana Di Kota Pekanbaru", Jurnal Ekonomi, Nomor 03, Vol. 22.

Miniard, Well Engel Perilaku Konsumen, Jilid 1, (Jakarta: Binarupa Aksara, 1994).

Mankiw, Gregory, Pengantar Ekonomi, Edisis kedua, (Jakarta: Penerbit Erlangga, 2003).

Amshari, M. M. (2019). Analisis Biaya Dan Efisiensi Produksi Dalam Ekonomi Islam. BALANCA: Jurnal Ekonomi dan Bisnis Islam, 1(1), 133-148.

Kirbrandoko, Jaka Wasana M, Pengantar Mikro Ekonomi, (Jakarta: Penerbit Erlangga, 1987).

Kuncoro, Mudrajat, Metode Kuantitatif Teori dan Aplikasi Untuk Bisnis dan Ekonomi, (Yogyakarta: UPP AMP YKPN, 2001).

Solimun, Multivariate Analysis Structural Equation Modelling (SEM) Lisrel dan Amos, (Malang: Penerbit Universitas Brawijaya, 2002).

Roger E. Meiners, Roger Le Roy Miller, Teori Ekonomi Intermediate, Terj. Hans Munandar, (Jakarta: PT. Raja Grafindo Persada, 2000).

Susanto, Philip Kotler, Manajemen Pemasaran di Indonesia, (Jakarta: Salemba Empat, 1999).

Suryawati, Teori Ekonomi Mikro, (Yogyakarta: UPP AMP YKPN, 2005).

Syekh, Sayid, Sekilas Pengantar Ilmu Ekonomi dan Pengantar Ekonomi Islam, (Jakarta: GP Press Group, 2013). 